\title{
The effectiveness of sodium tetradecyl sulfate in the treatment of wrist ganglia
}

\author{
Lawrence Ajekigbe FRCS(Glasg) Dip in Hand Surgery(Eur) ${ }^{1}$, John Stothard MD FRCSED FRCSED(Orth) ${ }^{2}$
}

L Ajekigbe, J Stothard. The effectiveness of sodium tetradecyl sulfate in the treatment of wrist ganglia. Can J Plast Surg 2006;14(1):28-30.

BACKGROUND: Ganglia are the most common benign soft tissue tumours of the hand. Although benign, a significant number of patients with wrist ganglia consult with their general practitioners, and ultimately the hand surgeon, complaining of pain. A great number of patients are concerned about the cosmetic appearance, and an equally significant number genuinely believe that the ganglion is a cancer. There are several management options resulting in varying degrees of success. These include observation only, surgical excision, aspiration only, aspiration with injection of methylprednisolone, and aspiration with injection of methylprednisolone and hyaluronidase. OBJECTIVE: The main objective was to investigate the effectiveness and safety of sodium tetradecyl sulfate as a sclerosing agent after aspiration of wrist ganglia.

METHODS: Initial data were collected prospectively during a period of 48 months. Following this, patients were sent a postal survey at least two years after they had received treatment to access the levels of recurrence and persistent complications.

RESULTS: In the short term, $90 \%$ of the patients achieved complete resolution after one episode of aspiration and injection. However, there was only a $65 \%$ cure rate after two to five years. Complications were few and not significant.

CONCLUSION: Sodium tetradecyl sulfate is an effective sclerosing agent after aspiration of wrist ganglia with an excellent short-term efficacy and a long-term cure rate comparable to that of surgical excision.

\section{L'efficacité du tétradécyl sulfate sodique dans le traitement des ganglions du poignet}

HISTORIQUE : Les ganglions sont les tumeurs bénignes des tissus mous les plus courantes sur la main. Bien que le problème soit bénin, bon nombre de patients qui présentent des ganglions du poignet consultent leur généraliste et, en dernier ressort, le chirurgien de la main pour cause de douleurs. De nombreux patients s'inquiètent de l'aspect esthétique de leur main, et ils sont tout aussi nombreux à penser qu'il s'agit d'un cancer. Il existe plusieurs possibilités de prise en charge, aux degrés de succès variés. Ces possibilités incluent l'observation, l'excision chirurgicale, l'aspiration, l'aspiration accompagnée d'une injection de méthylprednisolone et l'aspiration accompagnée d'une injection de méthylprednisolone et d'hyaluronidase.

OBJECTIFS : Le principal objectif consistait à explorer l'efficacité et l'innocuité du tétradécyl sulfate sodique comme agent sclérosant après l'aspiration de ganglions du poignet.

MÉTHODOLOGIE : Les données initiales ont été consignées prospectivement sur une période de 48 mois. Une enquête postale a ensuite été envoyée aux patients, au moins deux ans après le traitement, afin de connaître les taux de récurrences et de complications persistantes.

RÉSULTATS : À court terme, $90 \%$ des patients ont profité d'une résolution complète après un épisode d'aspiration et d'injection. Cependant, le taux de guérison ne s'élevait qu'à $65 \%$ au bout de deux à cinq ans. Les complications étaient rares et non significatives.

CONCLUSIONS : Le tétradécyl sulfate sodique est un agent sclérosant efficace après l'aspiration des ganglions du poignet. Il assure une excellente efficacité à court terme et un taux de guérison à long terme comparable à celui de l'excision chirurgicale.

Key Words: Aspiration; Fibrovein; Injection; Wrist ganglia

\section{PATIENTS AND METHODS}

\section{Stage 1}

All adult patients referred by general practitioners with virgin wrist ganglia (volar and dorsal) were entered into the study. One hundred thirty-two patients with a total of 137 wrist ganglia were recruited over 48 consecutive months. The last patient was entered in September 2001.

The procedures were carried out in the outpatient clinic using aseptic technique. The ganglion was prepared with chlorhexidine. Using a 25 gauge needle, the skin was infiltrated with $1 \mathrm{~mL}$ of $1 \%$ plain xylocaine. Some xylocaine was also injected into the sac, which not only anesthetized the sac but also diluted the content, thus facilitating aspiration. While tensing the ganglion between the middle and index fingers of one hand, a 19 gauge needle attached to a $10 \mathrm{~mL}$ syringe was introduced into the ganglion.
Suction was applied by retracting the plunger of the syringe; the needle was moved around within the sac while stabilizing fingers were used to express the content of the sac at the same time. Once the mass had collapsed, the plunger was released and the syringe removed, while the needle was left in situ. Depending on the volume of the aspirate, $0.25 \mathrm{~mL}$ to $0.5 \mathrm{~mL}$ of sodium tetradecyl sulfate (STD) was injected into the sac $(0.25 \mathrm{~mL}$ for less than $1 \mathrm{~mL}$ of aspirate and $0.5 \mathrm{~mL}$ for aspirate $1 \mathrm{~mL}$ and greater). The needle was then withdrawn and the site dressed with gauze, elastoplast and crepe bandages that were left in place for one week.

The patients were reviewed after six weeks and three months, and aspiration was repeated if indicated. Those with successful aspiration and injection were discharged to the care of their general practitioners with specific instructions to them and their family doctors for the patient to return should the ganglion recur.

${ }^{1}$ Department of Plastic Surgery; ${ }^{2}$ Deparment of Orthopaedic Surgery, Division of Trauma, The James Cook University Hospital, Middlesbrough, United Kingdom

Correspondence: Professor J Stothard, Department of Plastic Surgery, The James Cook University Hospital, Marton Road, Middlesbrough

TS4 3BW, United Kingdom. Telephone 01642-854214, fax 01642-854375, e-mail lorraine.sidgwick@stees.nhs.uk 


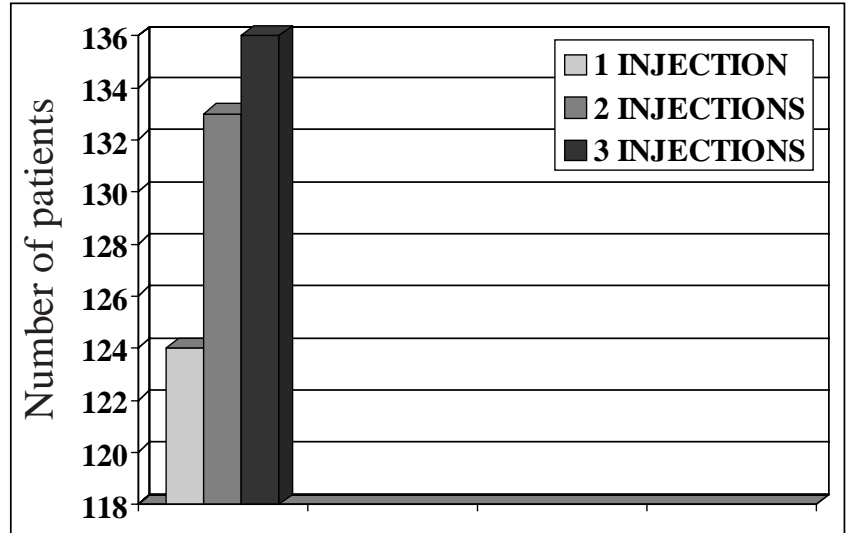

Figure 1) Success rates after one, two and three injections. Of the 137 ganglia aspirated and injected, 124 responded fully at the first attempt; this number increased to 133 and 136 at the second and third attempts, respectively

\section{Stage 2: Postal survey}

In May 2004, all of the patients that participated in stage 1 between September 1999 and August 2001 inclusively were sent a questionnaire. The questionnaire sought to detect the long-term continuing symptoms (ie, pain and stiffness), the recurrence rate and the overall effectiveness of this method of treatment. The questionnaire directly asked the patients whether they had been treated elsewhere for their ganglion since they were discharged.

The patients in this study, in common with sufferers of wrist ganglia in general, were young, occupationally and geographically mobile, and therefore often difficult to trace. Despite this, 55 of 132 patients were located, and 33 returned the questionnaires.

\section{Stage 1}

\section{RESULTS}

A total of 132 patients ( 52 men, 80 women) participated in the study (137 ganglia). Their mean age was 35.2 years.

Of the 137 ganglia aspirated and injected, 124 responded fully at the first attempt; this number increased to 133 and 136 at the second and third attempts, respectively. One ganglion was excised after a failed third attempt of aspiration and injection. Thus, there was a success rate of $90 \%$ for the first injection, with this percentage increasing to $97 \%$ after the second and $99 \%$ after the third injections (Figure 1).

\section{Stage 2}

Thirty-three of $55(60 \%)$ of the patients who returned their questionnaires had the following results:

- Weakness and pain improved following treatment (Figure 2).

- Symptoms of pain and weakness post-treatment were reported only among those who presented with these complaints before treatment and who failed to respond to the sclerosant (STD). More importantly, STD did not initiate chronic pain in any of the patients.

- Sixty-one per cent of those who complained of pain obtained relief, while $71 \%$ said the weakness improved following treatment (Figure 3).

- The recurrence rate after three to five years was 35\%. No patients had undergone surgical treatment.

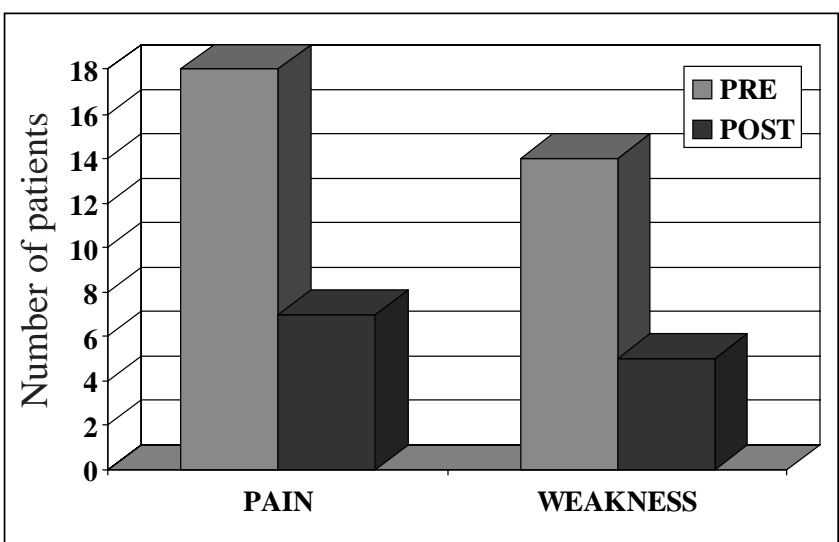

Figure 2) Symptoms before (PRE) and after (POST) aspiration and injection of the ganglia

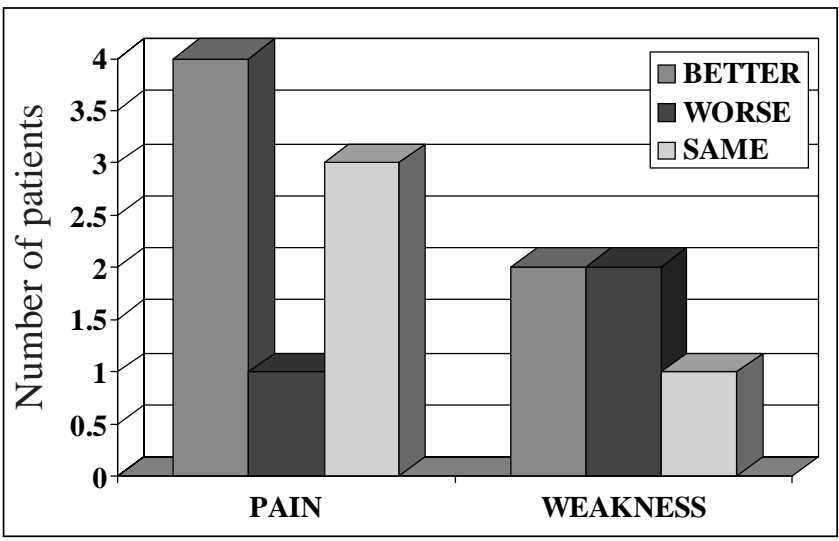

Figure 3) Degree of improvement in symptoms

\section{DISCUSSION}

Ganglia, while not life-threatening, are cosmetically unacceptable to a significant number of patients, and may cause pain and discomfort (1). There are several management options resulting in varying degrees of success. These include observation only (2), surgical excision (3), aspiration only, aspiration with injection of methylprednisolone, and aspiration with injection of methylprednisolone and hyaluronidase (4). However, today's hand surgeon can ill afford the operating room times required by this common tumour, and as such, an effective, carefully administered sclerosant satisfies both the patient's demand and the surgeon's limited resources.

Our success rate compared favourably with $75 \%$ achieved by Esteban et al (5) with aspiration only; 79\% with aspiration and injection of hydrocortisone by Holm and Pandey (6); and $89 \%$ with aspiration and injection of hyaluronidase and methyprednisolone reported by Paul and Sochart (4). Our slightly higher success rate of $90 \%$ (at the first attempt and $97 \%$ after the second injection) is probably due to our use of STD as the sclerosing agent.

The fears of complications that may arise from injecting sclerosant into the wrist joint expressed by Mackie et al (7) were not borne out by our experience. This is probably due to our strict selection criteria, avoidance of multiple puncture of the ganglion wall and the small amount of sclerosant that was 
injected. However, we agree with them that the procedure should be carried out only by consultants and supervised higher surgical trainees.

We found this procedure to be cost-effective: clinic attendance, aspiration and injection cost approximately $\$ 52.00$ compared with a day case operation that costs approximately $\$ 1,032.00$ (assuming only one visit is required for wound care). In these 137 ganglia, only one required surgery, so the saving in this one hospital was estimated to be $136 \times \$ 1,032.00=\$ 140,352$.

\section{REFERENCES}

1. Westbrook AP, Stephen AB, Oni J, Davis TR. Ganglia: The patient's perception. J Hand Surg [Br] 2000;25:566-7.

2. Dias J, Buch K. Palmar wrist ganglion: Does intervention improve outcome? A prospective study of the natural history and patientreported treatment outcomes. J Hand Surg [Br] 2003;28:172-6.

3. Wright TW, Cooney WP, Ilstrup DM. Anterior wrist ganglion. J Hand Surg [Am] 1994;19:954-8.

4. Paul AS, Sochart DH. Improving the results of ganglion aspiration by the use of hyaluronidase. J Hand Surg [Br] 1997;22:219-21.
ACKNOWLEDGEMENTS: We acknowledge the assistance of the Department of Clinical Audit of the James Cook University Hospital, Middlesbrough, United Kingdom in the administration of the questionnaires.

The present paper was presented in full at the meeting of the Federation of the International Societies for Surgery of the Hand in Budapest, Hungary on June 15, 2004.

5. Esteban JM, Oertel YC, Mendoza M, Knoll SM. Fine needle aspiration in the treatment of ganglion cysts. South Med J 1986;79:691-3.

6. Holm PC, Pandey SD. Treatment of ganglia of the hand and wrist with aspiration and injection of hydrocortisone. Hand 1973;5:63-8.

7. Mackie IG, Howard CB, Wilkins P. The dangers of sclerotherapy in the treatment of ganglia. J Hand Surg $[\mathrm{Br}]$ 1984;9:181-4. 